\title{
Water Flooding Combined With Infill Drilling at the Helvetian Strambu Field
}

\author{
Machedon V., Marcu D.
}

Petrom R. A, - ICPT, Romania

\begin{abstract}
Copyright 1895, Steering Committee of the Europeen IOR - Symposium.
This paper was presented at the 8th. European 10R - Symposium in Vienna, Austria, May 16 - 17, 1995

This paper was selected for prasentation by the Steering Committee, following review of informgtion contained in an abstract eubmitted by the author(s). The paper, as presented has not been reviewed by the Steoring Committee.
\end{abstract}

\section{ABSTRACT}

The Strâmbu reservoir is located in ten strata caps of the Helvetian period, transgressively and unconformably overlying the Oligocene, with dips ranging from $40^{\circ}$ on the west to $10^{\circ}$ on the east.

The reservoir rock, of the granular and predominantly psammitic type, has a pronounced inhomogeneity; oil density is $824 \mathrm{~kg} / \mathrm{m}^{3}$ (standard conditions), and oil viscosity is $16 \mathrm{mPa} . \mathrm{s}$ (initial reservoir conditions).

Production started in 1952 and until 1976 it was achieved exclusively under primary recovery. By the end of 1976, a high degree of energy depletion was noticed, with a recovery of only $15.2 \%$.

Waterflooding started as an experiment in December 1976 and it was gradually extended, yielding good results.

It was followed by the extension to a commercial scale by waterflooding and infill drilling.

Location of injection wells was designed in such a way as to comprise as much reservoir volume as possible by water displacement.

The combined effect of water injection, and at the same time, of infill driling led to an increase of oil production from 120 t'd in December 1976 to a maximum of $750 \mathrm{t} / \mathrm{d}$ in May 1985. At the beginning of 1995 recovery was $30 \%$ and incremental oil producrion owing to the combined effect of water injection and infill drilling srood for $1.833 .000 \mathrm{t}$.

An ultimate recovery of $34 \%$ is estimated.

\section{ANTRODUCTION}

Seismic surveys led to the discovery in 1950 , in the south-eastern part of the Getic Depression of some important structures consisting of rocks with good reservoir properties. Among these, hydrocarbon reservoirs belonging to the Helvetian and Meotian were outined on the Strambu structure (Fig.1) developed on the east-west direction, with a length of 3,000 $\mathrm{m}$ and a width of $1,500 \mathrm{~m}$, [1].

From among the numerous reservoirs produced by water injection in Romania starting from 1950, this case is interesting, owing to the existence of superimposed productive complexes, produced under primary recovery by commingled production, and not from each individual formation, to the rapid and favorable response to water injection inside the oil saturated zone and to the favorable effect of combined water injection and infill drilling.

The purpose of this article is to outline the main stages of the development of this reservoir, and their respective results.

\section{GEOLOGY}

The most important reservoir belonging to the Strâmbu strucrure (Fig.1), is developed in the Helvetian with a thickness comprised between $300 \mathrm{~m}$ and $350 \mathrm{~m}$. The Helvetian is of the pseudomassif type with bottom water, the depth of the initial oil/water contact being 1,140 m.s.s., [10]. The angular unconformity at the Meotian-Helvetian limit and the $F_{1}$ and $F_{2}$ fault system led to the creation of some tectonic and stratigraphic traps which enabled the Strâmbu reservoir to be formed within the Helvetian porous-permeable deposits.

\subsection{STRATIGRAPHY}

The Strâmbu structure developed in a sedimentary basin with the Oligocene formation, with a pronounced tectonics, as a subbase, the sediments being deposited over this relief, and affected by the orogenic movements during the Neogene.

The important volume of cores that was available allowed the petrographic, mineralogical and geochemical correlation of all encountered formations, starting with the Oligocene and ending with the Meotian, [1.2]. 

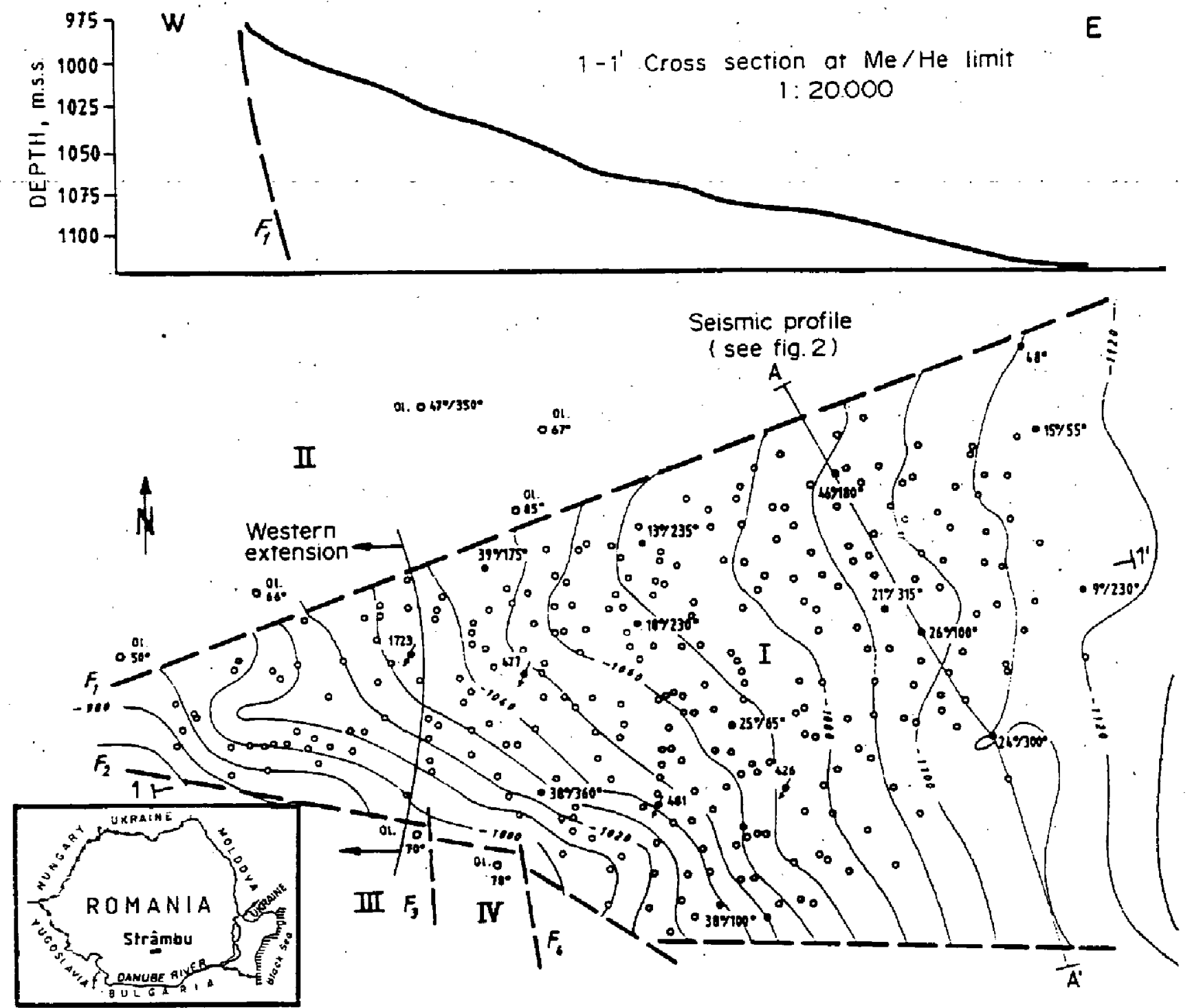

Fig. 1 - Structural map ot $\mathrm{Me} / \mathrm{He}$ limit

$1: 20000$

The development of the sedimentary basin included the following five periods:

a) the Paleogenic period - The core analyses permit. ted the outlining of Oligocene deposits, represented by fine grained and tight black clays, and partially, by dense shales, with fine mica grains, and light gray, fine grained sand intercalations. The orogenic movements markedly affected the Eocene and Oligocene formations, submitting them to intense episodes of plication and rupture, and breaking them into numerous fault blocks, with strata dips up to $70^{\circ} \ldots 80^{\circ}$ (Fig.2).

b) the Oligocene-Helvetian period - The end of the Paleogene is characterized by an ample regression accompanied by the emergence of Oligocene formations and then by their erosion as a result of the Savic orogeny, determining the occurrence of a stratigraphic gap to the beginning of the Helvetian, [1].

c) the Helvetian period - The Neogene transgression led to the extension of the sea basin and the resumption of the sedimentation process, the Helvetian deposits overlying transgressively and unconformably the Oligocene. Petrographic determinations on over 94 intervals from which cores were taken, revealed a great variety of rocks which give the Helvetian a complex and inhomogeneous character. Intercalations and thinningouts. facies variations are frequently encountered, pointing to the fact that sedimentation took place in a shallow sea area, more exposed to the action of sea currents. Over the entire duration of the Helvetian, the formations suffered folding movements, the faults at the level of the Oligocene being reactivated and affecting the entire pile. Dips at the level of the Helvetian are comprised between $10^{\circ}$ and $40^{\circ}$. Brown, fine grained sands with scarce: tight gray marls, and brown sandstones intercalations with calcite cement are predominant, [2]. Brown, tight, marls, with fine grained mica. and fine grained sandstones are frequently encountered, hosting a Helvetian microfauna represented by Globotruncana linneana (d'Orb), Lenticulina macrodisca (Reuss), Gyroidina neosoldanii (Brotzen) and Lagena laevis (Montagu), [1].

During the Helvetian, the westem part of the basin suffered a gradual emergence movement, concurrently with a downthrow of the eastern part, which influenced sedimentation, the basin waters withdrawing by the end of the period.

The result was the occurrence of a sedimentary gap which lasted until the beginning of the Pliocene, $[3,4]$. 


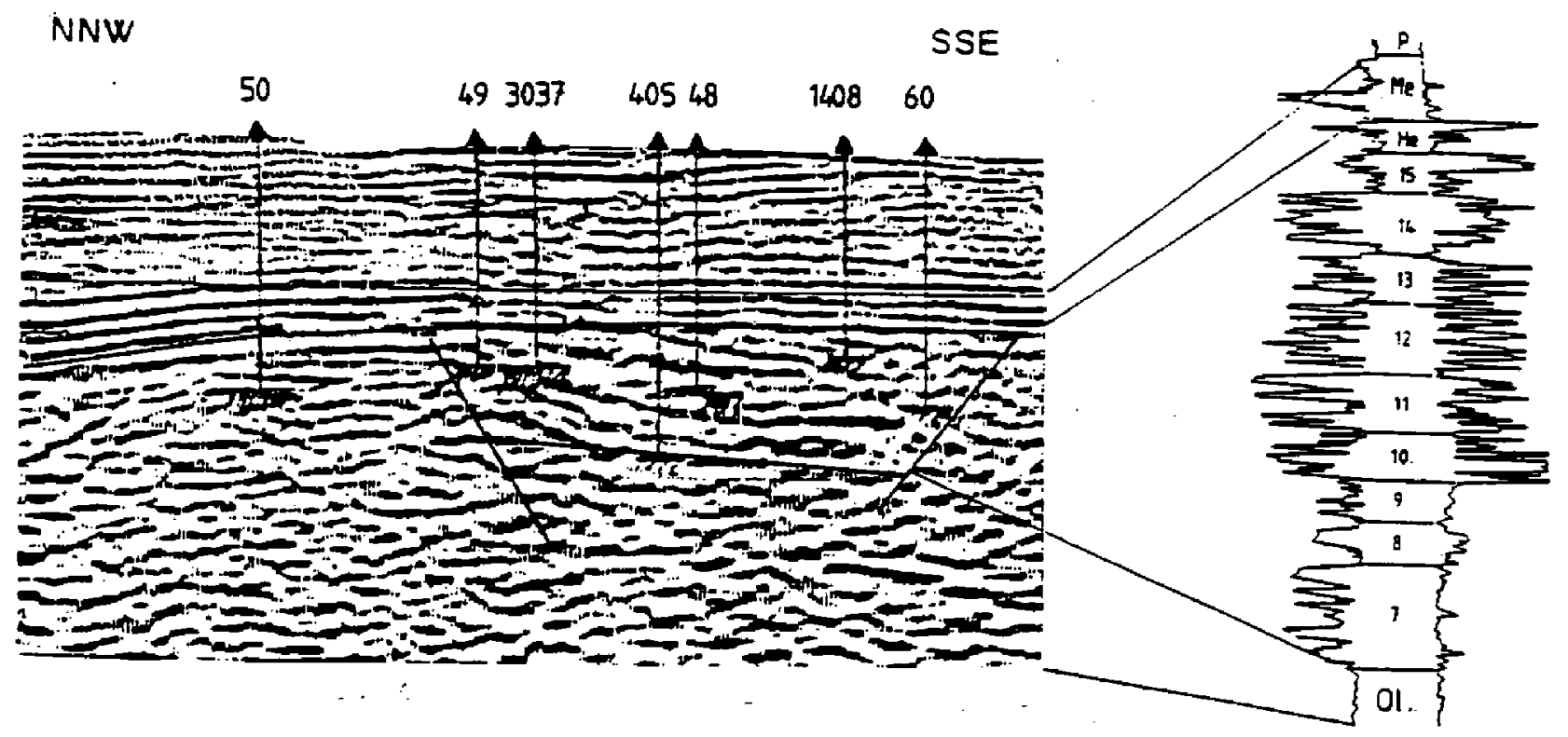

Fig. 2 - Depth seismic section and typical electric log $\Delta-A^{\prime}$ Seismic Profile

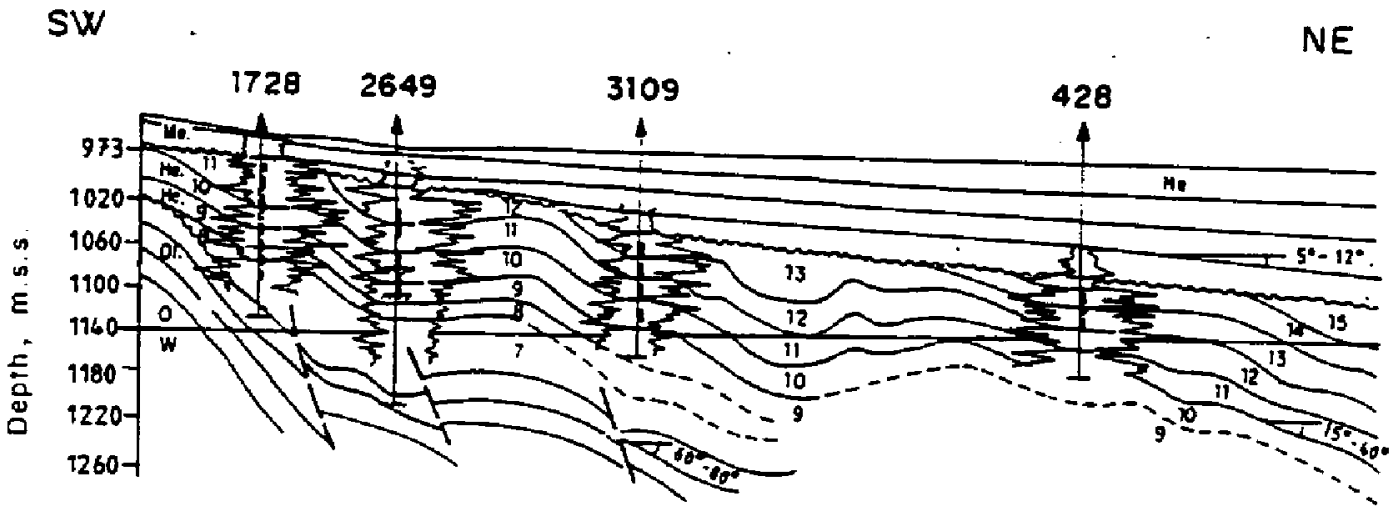

Fig. 3 - Cross section

d) the Helvetian-Meotian period - The geophysical data interpretation led to the separation of 10 pay zones. numbered from 7 (the oldest) to 16 (the latest) ( Fig. 3). This period is characterized by the emergence of the formations from the sea environment and their exposure to an erosion process until the beginning of the Pliocene, during which a new transgression took place, $[3,4]$.

e) the Pliocene period - The sedimentary basin extended its area beginning with the Pliocene, entirely developed and overlying transgressively and unconformably the Helvetian deposits. The Meotian is characterized by gray, fine grained sands, altemating with gray marls, [1, 2]. The Pontian is developed in an exclusively marly facies, with a continuous sedimentation. The Dacian and Helvetian are characterized by coarse grained sands, marls and thin coal intercalations. The Quaternary completed the sedimentation cycle, being represented by alluvial loess and terrace formations. During this period, the plication episodes had lower intensities, the Meotian strata having dips comprised between $5^{\circ}$ and $12^{\circ}$ (Fig. 4).

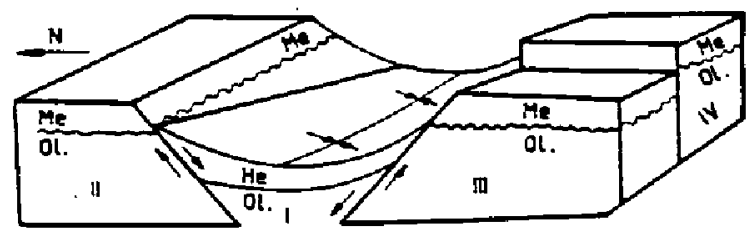

Fig. 4 - Tectonic scheme

\subsection{TECTONICS}

Starting with the Paleogene, the Strâmbu structure developed as regards the sedimentation area, the oldest known formations belonging to the Oligocene. Those have a pronounced tectonics and are broken into fault blocks, by two fault systems, $[1,2,3,4]$ :

$-F_{i}$ and $F_{z}$ system, with an approximate west-east orientation;

- $F_{z}$ and $F_{\downarrow}$ system, with a north-south orientation. 
Orogenic movements (Savic, at the end of the Paleogene; old Stirical, Intra-Burdigalian and new Stirical, lntra-Badenian) reactivated the two fault systems submitting the formations to a folding process. The resulting dips are designated in Fig. 1, [1]. Block II, located north of fault $F_{1}$, and blocks III and IV, located south of fault $F_{2}$ (Fig. 1) were subject to several positive movements, being onshore areas until the Pliocene when they became offshore areas as a result of the basin extension through transgression. On the other hand, the $F_{1}-F_{2}$ system determined the collapse of the block I (Fig. 4) at the beginning of the Miocene and the formation of a graben, where, during the Helvetian, marine conditions developed, marked by two different evolutions:

a) the eastern area was submitted to a subsidence movement and,

b) the western area was submitted to an emergence movement.

$F_{1}$ and $F_{2}$ fault slips are comprised between $50 \mathrm{~m}$ and $100 \mathrm{~m}$.

The Pliocene was affected to a lesser extent by the succeeding orogenic movements (Fig. 2) resulting in a quasi-horizontal Meotian, with dips between $5^{\circ}$ and $12^{\circ}$, with a practically complete structural arrangement.

\section{PHYSICAL PARAMETERS}

The reservoir rock consists of poorly consolidated sand or sandstones layers, with a coarse, medium or fine grain, reduced by erosion and containing marly or inarly-sandy intercalations, with thicknesses comprised berween $1 \mathrm{~m}$ and $5 \mathrm{~m}$, appearing as lenses.

The porous-permeable strata were grouped into complexes, separated by marly or mariy-sandy intercalations, discontinuous ones. Besides this physical reservoir characteristic, and bearing in mind that production was commingled, by opening most of productive complexes, in all wells, one can get the image of the existing situation in 1976 [5], i.e. the image of a single reservoir, not affected by faults. There are exceptions to this image, caused by several new wells drilled after commencement of water injection which produced by natural flowing, with important flow rates and pressures, due to their marginal position.

The geophysical investigations as well as the core analysis results led to the idea of a pseudomassif type reservoir (with bottom water).

The inhomogeneity coefficients have, according to Dikstra-Parsons, a value of $0.69 / 0.81$, and according to Lorenz, of $0.53 / 0.56$ for permeabilities perpendiculariparallei to the stratification.

The reservoir storing capacity*! has the highest values in the western part of the reservoir and has a tendency to decrease from the south-west to the north-east.

The average values of the main physical parameters of the rock and contained fluids are given in Table 1.

*) Porosity times oil samuration
Table 1

AVERAGE VALUES OF THE MAIN PHYSICAL PARAMETERS

Depth

Temperature

Pressure

- initial reservoir

- current reservoir

- bubble point

Effective thickness

Porosity

Absolute permeability

- parallel with the layer

- perpendicular to the layer

Interstitial water saturation

Oil saturation

- initial

- current

Oil gravity

(standard conditions)

Relative gas density (air = 1)

Oil viscosity

(initial reservoir conditions)

$\frac{\mathrm{mPa} \cdot \mathrm{s}}{\mathrm{cP}}$

$\frac{16}{16}$

Solution ratio

(initial reservoir conditions) $\frac{\mathrm{Sm}^{3} / \mathrm{m}^{3}}{\mathrm{Ft}^{3} / \mathrm{Bbl}} \quad \frac{58}{325}$

Oil volume factor

(initial reservoir conditions)

\section{PRODUCTION PERFORMANCE}

\subsection{PRODUCTION BY PRIMARY RECOVERY}

Production started in 1952, and the maximum number of wells was 63 , in 1957 (Fig.5 g).

In most cases, the wells produced initially by narural flowing, over time intervals comprised between 3 months and 3 years, with flow rates of $15 \mathrm{t} / \mathrm{d}$ to $30 \mathrm{td}$, which rapidly decreased calling for proceeding to production by pumping. 
I'n-'most cases wells were initially opened over short initervals at the base of the productive complexes" pile. during the first production years, with other intervals adied. in stages, leading to perforated intervals on the westem part of the reservoir, which summed up, measured over $40 \mathrm{~m}$ within the same well (Fig 3). Difficulties related to correlation over long distances and the rush for an important immediate production led to a commingled exploitation, not selectively centered on productive complexes (Fig.3), [5,6].

Production was obtained under dissolved gas drive. It was to be expected to get a reduced primary recovery. I5 years after production commencement, the pay zone was extended to the west (Fig. I), with an initially unknown area, thus obtaining, during continuation of production. a group of wells, within this western extension, with pressures below initial reservoir pressure, but with oil flow rates markedly superior to those comprised in the area where production started in 1952 (Table 2), [7].

Table 2

WELL DISTRIBUTION ACCORDING TO CLASSES OF OIL FLOW RATES

\begin{tabular}{|c|c|c|c|c|}
\hline $\begin{array}{c}\text { Class of Oil } \\
\text { Flow Rate, } \\
\text { vd. w }\end{array}$ & \multicolumn{2}{|c|}{ Old Area* } & \multicolumn{2}{|c|}{$\begin{array}{c}\text { New Area** } \\
\text { (Westem Extension) }\end{array}$} \\
\cline { 2 - 5 } & $\begin{array}{c}\text { No. of } \\
\text { Wells }\end{array}$ & $\%$ & $\begin{array}{c}\text { No. of } \\
\text { Wells }\end{array}$ & $\%$ \\
\hline $0 \ldots 1$ & 23 & 56 & 1 & 9,1 \\
\hline $1 \ldots 2$ & 8 & 19,5 & 1 & 9,1 \\
\hline $2 \ldots 3$ & 4 & 9,8 & 2 & 18,1 \\
\hline $3 \ldots 5$ & 4 & 9,8 & 2 & 18,1 \\
\hline $5 \ldots 8$ & 2 & 4,9 & - & - \\
\hline $8 \ldots 13$ & - & - & 5 & 45,6 \\
\hline
\end{tabular}

*) 41 wells with a total production of $69.4 \mathrm{t} / \mathrm{d}$ or an average proauction of $1.7 \mathrm{t} / \mathrm{d}$, well.

**) II wells with a total production of $45.6 \mathrm{t} / \mathrm{d}$ or an average production of $4.1 \mathrm{t} / \mathrm{d}$, well.

During the first years of exploitation production increased rapidly, alongside the number of wells, reaching, in 1956, a maximum value of $340,000 \mathrm{t}$ through 61 wells $(930 \mathrm{t} / \mathrm{d}: 15.2 \mathrm{t} / \mathrm{d}$. well; Fig. 5a, $5 \mathrm{~b}$. 5g).

Further on, production decreased rapidly, $98,000 \mathrm{t}$ being oorained through 63 wells $(268 \mathrm{t} / \mathrm{d} ; 4.3 \mathrm{t} / \mathrm{d}$. well) in 1961, and 42,000 $\mathrm{t}$ through 49 wells $(115 \mathrm{t} / \mathrm{d}$ : $2.5 \mathrm{t}$ d, well) in 1968 . Starting with 1969 a reversal in the production trend was wimessed brought about by bringing in the 11 wells in the western extension (Fig. 1, 5a, 50j. In 1976, the year in which the design of the exploitation of the entire reservoir was reconsidered, production amounted to $48,800 \mathrm{t}$ through 52 wells ( 133 $\mathrm{t} / \mathrm{d} ; 2.6 \mathrm{v} / \mathrm{d}$, well), [5].

Watercut increased slowly reaching $20 \%$, in 1976 (Fig. 5d).
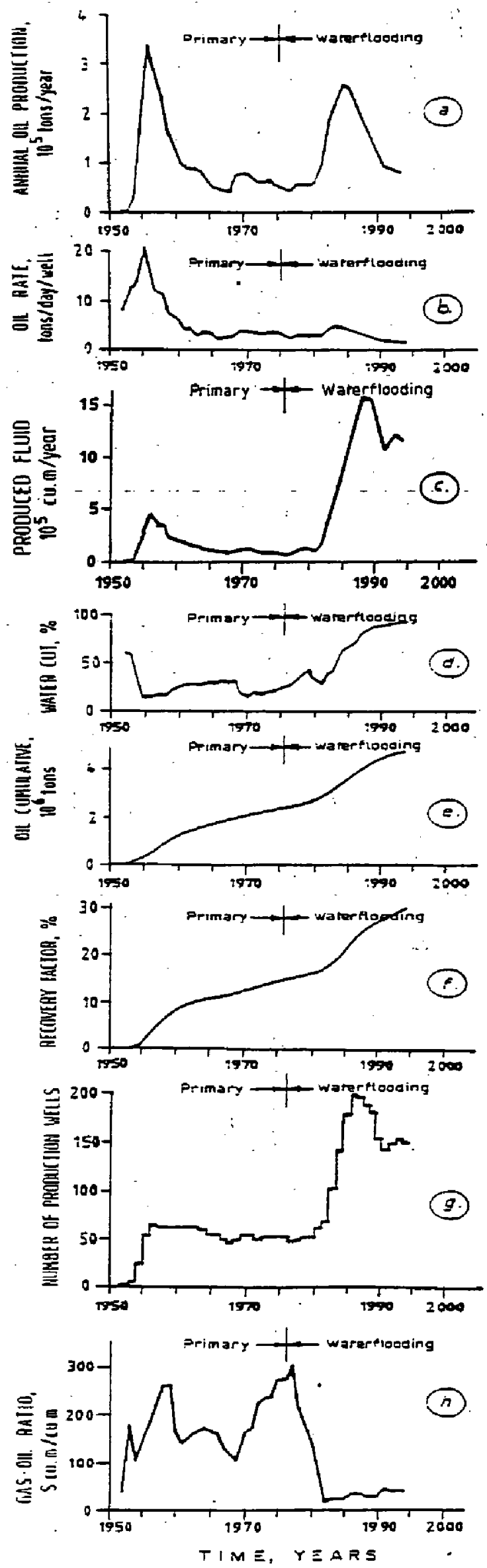

Fig. 5 - Production history 
The gas-oil ratio reached the value of $280 \mathrm{Sm}^{3} / \mathrm{m}^{3}$ in 1958 , then it decreased and remained $150 \mathrm{Sm}^{3} / \mathrm{m}^{3}$ until 1968 when it started increasing again after commencement of production from the western extension, after which it reached a maximum of $300 \mathrm{Sm}^{3} / \mathrm{m}^{3}$ in 1977 , followed by a rapid decrease (Fig. $5 \mathrm{~h}$ ). By the end of 1976 , the production of the entire reservoir had reached $120 \mathrm{t} / \mathrm{d}$ (Fig. $5 \mathrm{a}$ ), the production of an average well being $2.3 \mathrm{t} / \mathrm{d}$ (Fig. $5 \mathrm{~b}$ ), the produced oil cumulative $2,440,000 \mathrm{t}$ ( $\mathrm{Fig}$. $5 \mathrm{e}$ ), and the recovery, $15.2 \%$ (Fig. 5f).

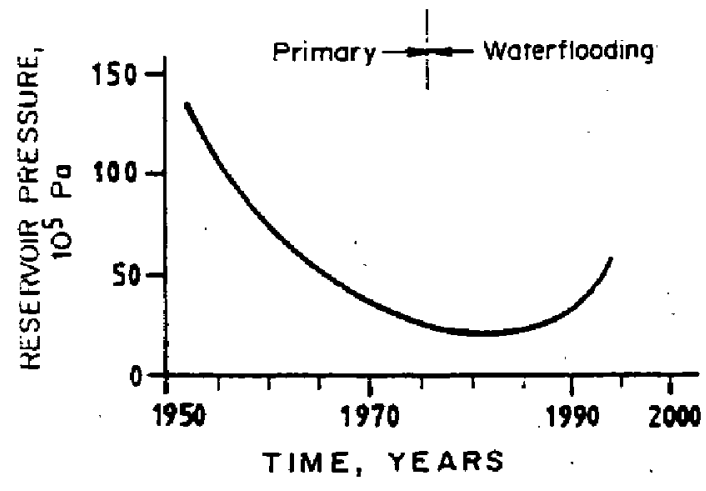

Fig. 6-Reservoir pressure vs. time

By reviewing the graphs shown in Fig. 5 it can be inferred that this is a normal behaviour for a reservoir produced under dissolved gas drive.

The evaluations made by the end of 1976 . [5] pointed to the fact that:

- recovery had reached $15.2 \%$ after about 25 years of production by exclusively primary recovery;

- production continued to slowly decrease and, provided the number of producers remains constant, by 2005 , about $54 \mathrm{t} / \mathrm{d}$ will be obtained, with a recovery of $20.2 \%$

- though the average daily flow rate of a well will still have a value of about $1 \mathrm{t} / \mathrm{d}$. well, production will be performed with major difficulties and low profitability due to a poor production and to the expendirures for keeping under operation conditions wells several decades old;

- the actual number of producers was likely to decrease continuously, accompanied by a pronounced decrease in the daily production alongside an increase of the production life.

Furthermore, it should be borne in mind that the estimated value of about $1 \mathrm{t} / \mathrm{d}$, well of the average flow rate predicted for 2005 was mostly due to the group of 11 new wells brought in 15 years later, and that after 30 years, the average flow rate of a well (an old one) from the group of 41 wells (Tabie 2) would be much below 1 $t / d$, well, the very existence of those wells being most unlikely.

Under these circumstances, the attainment of the ultimate recovery under primary recovery, as previously assumed had low chances of being achieved, and the production economic efficiency decreased dramatically. As mentioned in this study [5], the reservoir. by its physical parameters and its depletion stage at that moment, was a good candidate for experimental water flooding.

Prior to commencement of water flooding, watercut had ranged between $15 \%$ and $30 \%$ (Fig. $5 \mathrm{~d}$ ).

\subsection{WATERFLOODNG EXPERIMENT}

In general, it is recommended that waterflooding be performed selectively, making sure that the producers are open to the laver being injected.

The strict application of this requirement for the Strâmbu Helvetian would have meant either the existence of a separate network of wells (injection; production) for each complex, or a very long production life with a single network, to be withdrawn from bottom to top. Economically, in both cases, production was very close to the unprofitability zone.

For this particular reservoir made of strata caps, peripheral water injection line (below the oil-water contact):

- would have a favorable effect only on an area close to the water injection interval of each complex;

- would suppose long time intervals until the appearance of the effect, due to the large volume of the aquiferous basin:

- would not allow a separate monitoring, by complexes, of the effect, due to the discontinuities of marly separations and to the opening of almost all wells into all productive complexes.

The injection exclusiveiy inside the oil saturated zone would suppose:

- the risk of water channeling towards the downstream producers especially in the westem part of the reservoir. where dips have values up to $35^{\circ}$;

- a markedly different volumetric displacement efficiency between the wells upstream and downstream of the injecting well;

- the impossibility to monitor separately, by individual complexes, the effect of water injection, due to the discontinuities of the marly separations and opening of almost all wells in all productive intervals.

Water injection, inside the oil saturated zone, over the entire productive pile, as well as on a peripheral line, by opening also the injectors under the oil-water contact, would determine oil displacement by water involving a much larger reservoir volume. but at the same time would reduce the possibilities for rapid action related to production control.

In view of obtaining basic information in connection with receptivity, effect on production, response time, actual channeling risk: it was decided to perform an experimental stage of water injection. Each central well of an injection pattem (Fig. 1,7) was to be opened to all perforated complexes for all output wells of the respective pattenn. Thus it was hoped to be able to notice the difference in effect between producers located upstream or downstream of the injector, as well as the possible influence on wells located outside the pattern. It was estimated that, in the case of a successful water injection experiment, and of commercial production by this method, oil saturation would then be reduced from 


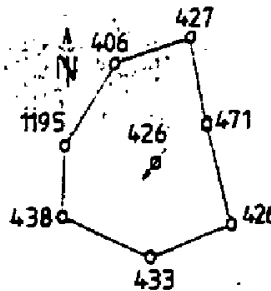

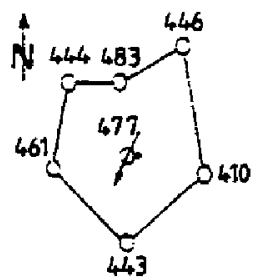
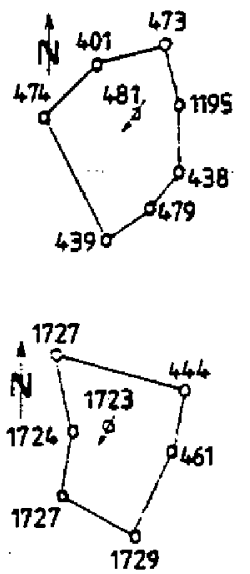
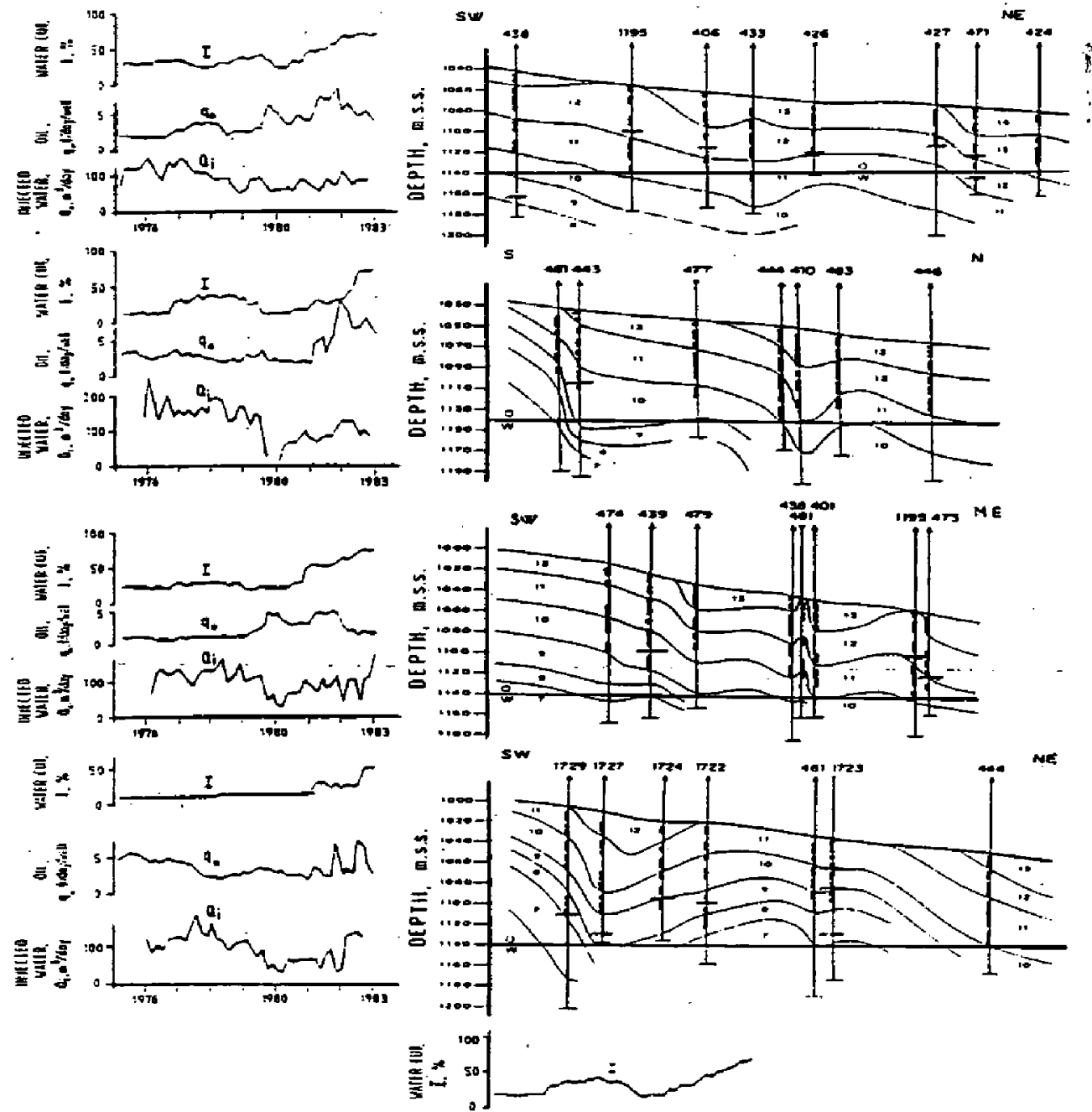

ALL PATTERNS

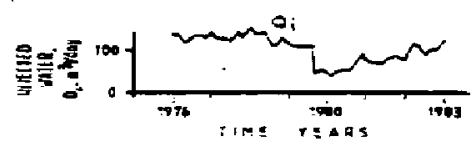

Fig. 7 - Production behoviour by waterflooding, of the four experimental patterns.

0.61 . which was the average value existing by the end of 1976 [5], to 0.46 by the end of the production life, with an ultimate recovery of $34 \%$.

The decision made in 1976, to test water injection was encouraged by the important value of oil saturation at that time $(61 \%)$, by the low value of daily production (120 t/d, reservoir; $2.3 \mathrm{t} / \mathrm{d}$, well) and of the recovery $(15.2 \%)$, by the existence of 49 wells under a good technical condition and of some idle wells which could be used for injection. by the good water receptivity of the Helvetian, by the favorable value of the mobilities ratio and by the possibility to obtain and treat the water necessary for injection, by the important value of the original oil in place, by the poor value of the ultimate recovery to be achieved under dissolved gas drive and by the long duration in which the latter could have been achieved. It was estimated that in the case of commencement of commercial production by water injection the ultimate recovery would be superior by a minimum of $10 \%$ to the calculated value for production under dissolved gas drive.

The unfavorable factors were the pronounced inhomogeneity of the reservoir, the uneven energy exhaustion of various complexes or areas of the latter, which increased the risk of channeling of injected water, especially in areas with high dips, and the possibility of stimulating sand encroachment. For these reasons, in the case of commencement of commercial production by water injection, it was recommended to proceed carefully to such an extension, by strictly limiting the liquid flow rates of the producers to values slightly lower than the maximum admitted ones, even with the risk of entailing a slight increase of the production life. This recommendation was admitted , as abandoning a well would have meant losses either due to leaving a reservoir area undrained by water, or to the need to drill a replacement well.

Experimental water injection was achieved using 4 partems (Fig. 1, 7) starting with December 1976 and January 1977. As expected, injection flow rates were 

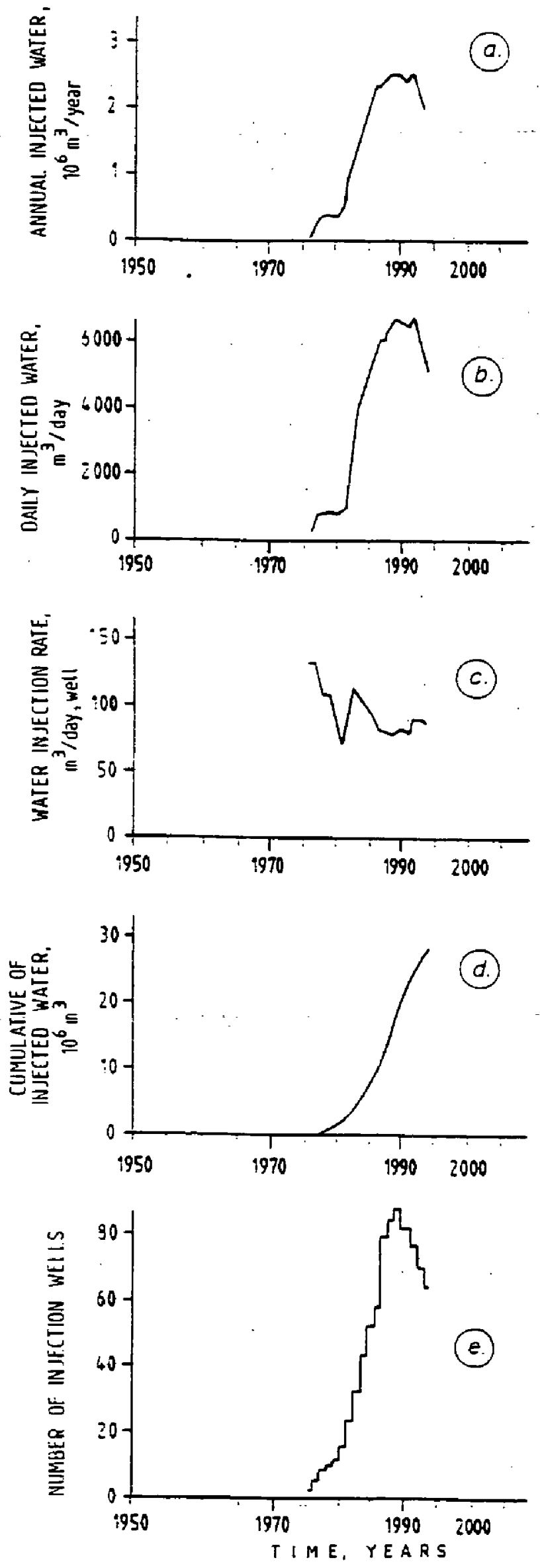

Fig. 8 - Woterflooding history comprised between $100 \mathrm{~m}^{3} / \mathrm{d}$, well and $200 \mathrm{~m}^{3} / \mathrm{d}$, well, and the effect of injection over oil production became obvious first by stopping the decline and then by increasing the oil flow rate (Fig. 7), [6, 7].

Owing to the very good reservoir receptivity, the gradual transition to the commercial production stage by waterflooding was commenced even before obtaining the maximum effect on production, attributable to waterflooding within the 4 patterns, [7].

\subsection{COMMERCIAL PRODUCTION BY WATERFLOODNG}

In view of the gradual transition to commercial production by waterflooding, it was necessary to design and then to achieve the networks of injection or production wells. Well location was established taking into account:

- the need to inject water into each productive complex starting from the uppermost part in the most favorable positions to displace oil in the most efficient and uniform manner;

- the need to have, within each complex, sufficient producers around an injector in an adequate arrangement to minimize as much as possible the risk to leave behind areas unexposed to the effect of injection;

- the need to fully exploit the operating wells and to operate again some of the previously abandoned wells;

- the relief of the basin and the oil production of the wells at that moment.

The generally reduced reservoir dip, the lack of some water-oil contacts of a considerable length, and the production method previously used (the opening of practically all productive intervals, which was the case with all wells)determined the application of an internal injection line at the commencement of waterflooding, over the entire productive section, and into the first complex below the oil-water contact so as to include production from the area comprised between this contact and the first row of producers above it. It was supposed that the flow of the injected water directly into the oil saturated area of each complex would cause a more rapid response of the producers; the oil-water contact would start to rise from the very beginning of the injection process. During the first stage, the new producers were to be opened selectively, by complexes, from bottom to top. An important increase of production at the level of the entire reservoir was recorded (Fig. $\mathbf{5 a}$, 5b) with a shor response time and no significant channeling: $[s, 9]$.

The values of the injection flow rates were permanently monitored and correlated with the behaviour of the producers from the influence area. Thus, siruations were noticed and corrected. such as wells within watercut cląsses of over $60 \%$ which had either a low gross flow rate (up to $15 \mathrm{~m} / \mathrm{d}$, well) and a net flow rate below the average reservoir value, or a high gross flow rate $\left(40 \mathrm{~m}^{3} / \mathrm{d}\right.$, w to $60 \mathrm{~m}^{3} / \mathrm{d}_{\text {; }}$ w) and an equally high net flow rate (over $8 \mathrm{vd}, w$ ). Those facts outlined the need to make slight changes in the values of the injection flow rates, or the calculared production rates, as necessary, to 
periodically reconsider the network of injection or production weilis and to differentiate three classes of injection flow rate depending on the effective thickness of the area under consideration:

$-120 \mathrm{~m}^{3} / \mathrm{d}, \mathrm{w}$ in the western area where the effective thickness is comprised between $40 \mathrm{~m}$ and $60 \mathrm{~m}$;

$-80 \mathrm{~m}^{3} / \mathrm{d}$. w in the central area, where the effective thickness is comprised between $20 \mathrm{~m}$ and $40 \mathrm{~m}$;

$-50 \mathrm{~m}^{3} / \mathrm{d}$. $w$ in the eastern area, where the effective thickness is comprised between $10 \mathrm{~m}$ and $20 \mathrm{~m}$.

During the development of the reservoir a weil may be turned from a "producer" into an "injector" when watercut reaches high values.

A ratio above the unit between the volume of injected water and the total volume of produced fluids was sought in order to start partial restoration of the reservoir pressure (Fig. 6).

in the period between the beginning of 1978 and the end of 1981 the water injection flow rate was basically maintained constant at $800 \mathrm{~m}^{3} / \mathrm{d}$ through 8 wells (Fig. 8a, 8b, 8c) whereas the production of an average well remained at about $3 \mathrm{t} / \mathrm{d}$,well (Fig. 5b) and the production from the entire reservoir increased from $120 \mathrm{t} / \mathrm{d}$ through 40 wells, to $180 \mathrm{t} / \mathrm{d}$ through 60 wells (Fig. 5a. 5g).

From the very beginning of 1982 , the combined effect of waterflooding and infill drilling became obvious. The oil production of the entire reservoir increased, $[7,8,9$, 10, 11]:

- by the end of 1982 to $350 \mathrm{t} / \mathrm{d}$ through 89 wells
$(4.0 \mathrm{t} / \mathrm{d} . \mathrm{w}$; Fig. $5 \mathrm{a}, 5 \mathrm{~b}, 5 \mathrm{c}, 5 \mathrm{~g})$, waterflooding being $3,200 \mathrm{~m}^{3 / d}$ through 29 wells $\left(110 \mathrm{~m}^{3} / \mathrm{d}\right.$, w; Fig. $8 \mathrm{~b}, 8 \mathrm{c}$, $8 \mathrm{e})$;

- by the end of 1983 , to $570 \mathrm{t} / \mathrm{d}$ through 114 wells ( $5 \mathrm{t} / \mathrm{d}, \mathrm{w}$; (Fig. $5 \mathrm{a}, 5 \mathrm{~b}, 5 \mathrm{c}, 5 \mathrm{~g}$ ), waterflooding being $4,000 \mathrm{~m}^{3} / \mathrm{d}$ through 32 wells $\left(125 \mathrm{~m}^{3} / \mathrm{d}\right.$, well; Fig. $8 \mathrm{~b}$, $8 \mathrm{c}, 8 \mathrm{e})$;

- by the end of 1984 , to $670 \mathrm{t} / \mathrm{d}$ through 166 wells $(4 \mathrm{t} / \mathrm{d}, \mathrm{w})$; waterflooding being $5,000 \mathrm{~m}^{3} / \mathrm{d}$ through 45 wells $\left(111 \mathrm{~m}^{3} / \mathrm{d}\right.$, w );

- by the middle of 1985 , to the maximum value of $750 \mathrm{t} / \mathrm{d}$ through 179 wells $(4.2 \mathrm{t} / \mathrm{d}, \mathrm{w})$, waterflooding being 5,100 $\mathrm{m}^{3}$ through 49 wells $\left(104 \mathrm{~m}^{3} / \mathrm{d}, \mathrm{w}\right)$;

- by the middle of 1986 , to the maximum, stable, value of $750 \mathrm{vd}$, but through 205 wells $(3.7 \mathrm{t} / \mathrm{d}, \mathrm{w})$, waterflooding being $6,200 \mathrm{~m}^{3} / \mathrm{d}$ through 66 wells $\left(94 \mathrm{~m}^{3} / \mathrm{d}, \mathrm{w}\right)$.

Further on, oil production steadily decreased:

. - $448 \mathrm{t} / \mathrm{d}$ by the end of 1988 , through 187 wells $(2.4 \mathrm{t} / \mathrm{d}, \mathrm{w})$, waterflooding being $6,600 \mathrm{~m}^{3} / \mathrm{d}$ through 86 we!ls $\left(77 \mathrm{~m}^{3} / \mathrm{d}\right.$, w);

- $360 \mathrm{t} / \mathrm{d}$ by the end of 1989 , through 177 wells $(2.0 \mathrm{Vd}, \mathrm{w})$ waterflooding being $6,770 \mathrm{~m}^{3} / \mathrm{d}$ through 88 wells $\left(77 \mathrm{~m}^{3} / \mathrm{d}, \mathrm{w}\right)$;

- $314 \mathrm{t} / \mathrm{d}$ by the end of 1990 through 152 wells $(2.1 \mathrm{t} / \mathrm{d}, \mathrm{w})$, waterflooding being $6,705 \mathrm{~m}^{3} / \mathrm{d}$ through 82 wells $\left(82 \mathrm{~m}^{3} / \mathrm{d}\right.$, w);

- $224 \mathrm{t} / \mathrm{d}$ by the end of 1992 , through 147 wells $(1.5 \mathrm{v} / \mathrm{d}, \mathrm{w})$, waterflooding being $6,530 \mathrm{~m}^{3} / \mathrm{d}$ through 75 wells $\left(87 \mathrm{~m}^{3 /} \mathrm{d}, \mathrm{w}\right)$;

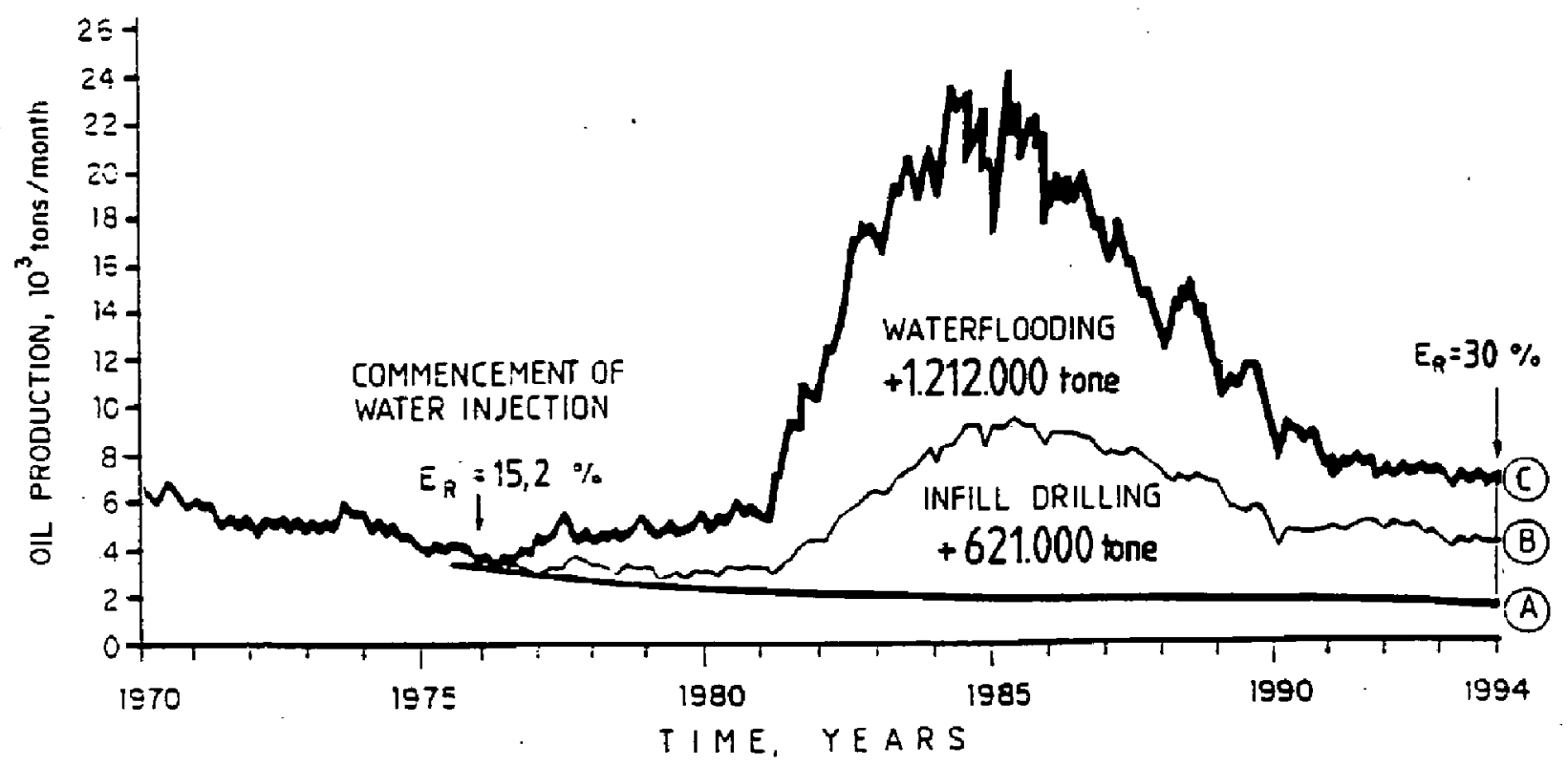

Fig. 9 - Incremental production obtained by waterflooding and infill drilling

A Entire reservoir production under PRIMARY, based on the assumption that only the 49. producers existing in December 1976 will coninue to produce

(B) Entire reservoir production under PRIMARY, bosed on the 49 producers in Eecember 1976 plus subsequent infill drilled wells.

(C) Acjual production from the entire reservoir, with WATERfLOODING and INFILL GRILLING 
- $213 \mathrm{t} / \mathrm{d}$ by the end of 1994 , through 150 wells (1.4 $\mathrm{v} d \mathrm{~d}, \mathrm{w})$, waterflooding being $5,230 \mathrm{~m} / \mathrm{d}$ through 63 wells $\left(83 \mathrm{~m}^{3} / \mathrm{d}\right.$, well).

In Fig. 9 it can be noticed that as compared to the primary production which would have been obtained exclusively from the 49 wells existing in December 1976 (curve A), the incremental production obtained after that date is primarily attributable to water injection (curve C) and secondly to infill drilling (curve B). As of January 1995 the incremental production resulted from the combined effect of water injection and infill drilling was $1,833,000$ t oil, with a recovery of $30 \%$ (Fig. 10).

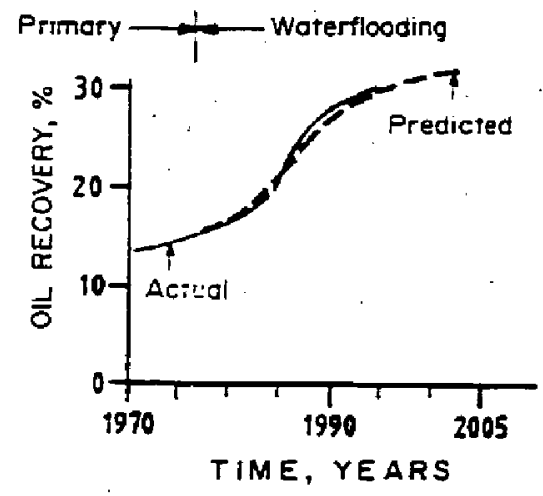

Fig. 10 - Comparison between
the 1977 predicted oil recovery
and the actual oil recovery.

\section{CONCLUSIONS}

1. The Strâmbu reservoir is located within ten complexes appearing as strata caps, of the Helvetian age., transgressiveiy and unconformably. overlying an Oligocene basin. with dips comprised between $40^{\circ}$ on the west and $10^{\circ}$ on the east.

2. The reservoir rock has an important degree of inhomogeneiry. Oil: has a density of $824 \mathrm{~kg} / \mathrm{m}^{3}$ (under standard conditions) and a viscosity of $16 \mathrm{cP}$ (under initial reservoir conditions).

3. Production began in 1952, and for a period of 25 years it was obtained under primary recovery; with a recovery of $15.2 \%$ by the end of 1976 , when the energy depletion reached an advanced stage.

4. Testing of waterflooding started in December 1976. It was decided to proceed to commercial production by waterflooding.

5. The basic principle of waterflooding consists in:

- opening of injection wells and waterflooding into all productive complexes and into the first complex located below the oil -water contact:

- successive opening of new producers from bottom to top. as production cessed in the complex produced at a cerrain period.

6. Injection wells were located as to ensure oil displacement by water from as much reservoir volume as possible. The producers/injectors ratio is $3: 1$.
7. In view of production by waterflooding, 251 producers and 18 injectors were drilled.

8. As of January 1, 1995:

- the recovery had reached $30 \%$;

- an incremental production of $621,000 \mathrm{t}$ was obtained owing to infill drilling, and of $1,212,000 \mathrm{t}$, due to water injection;

- it is estimated that the uitmate recovery will be $34 \%$.

\section{REFERENCES}

I. MUTHLAC,V, IONESI, N.:. 'Romania's Geology", Tecbnical Publishing House, București, 1973.

2. RĀDULESCU, D., ANASTASIU, N.: 'Petrology of Sedimentation Rocks', Didactic and Peda. gogical Publishing House, București. 1977.

3. TRIMBBTA, I., ENACHE, P., et al. : 'Final Report on Seismic Prospecting in the Domnești-Boțești Area"' 1985.

4. IORDAN; Gl. MIRITOIU, I., et al.: " Report on Seismic Prospecting in the Drăgăiești-Vâlcele Area", 1984

5. MACHEDON, V., LUPAN, M.: 'The Increase of the Recovery Factor on the Oil Reservoirs from the Strâmbu Helvetian"', I.C.P.T. Câmpina, 1976.

6. MACHEDON, V.: ..." Evaluation of the Water Injection Experiment on the Strâmbu Helvetian", I.C.P.T. Câmọina. 1977.

7. MACHEDON, V.: "Production, Evaluation and "Suostantiation Study for the Investiments Related to the Strambu Helvetian Reservoir", I.C.P.T. Câmpina, 1982.

8. MACHEDON, V., MATEI, V.: "Production and Suostantiation Study For the Investments Related to the Strâmbu Helvetian Reservoir", I.C.P.T. Câmpina. 1983.

9. MACHEDON, V., PURDEL, V.: "Production, Evaluation and Substantiation Study for the Investments Related to the Strâmbư Helvetian Reservoir", I.C.P.T. Câmpina, 1989.

10. VERNESCU, A.: "Project for Methodological Norms Regarding Classification, Computation, Homologation and Outlining of Oil Reserves",

- I.C.P.T. Câmpina, 1990.

11. RUSU, D., MARCU, D.: "Study for Production of the Strâmbu Helvetian Reservoir" I.C.P.T . Câmpina, 1993. 